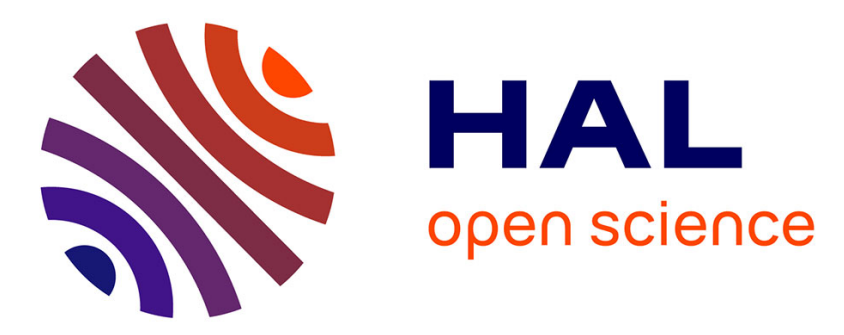

\title{
Molecular Electrochemical Catalysis of the CO 2 -to-CO Conversion with a Co Complex: A Cyclic Voltammetry Mechanistic Investigation
}

Claudio Cometto, Lingjing Chen, Elodie Anxolabéhère-Mallart, Claire Fave, Tai-Chu Lau, Marc Robert

\section{To cite this version:}

Claudio Cometto, Lingjing Chen, Elodie Anxolabéhère-Mallart, Claire Fave, Tai-Chu Lau, et al.. Molecular Electrochemical Catalysis of the CO 2 -to-CO Conversion with a Co Complex: A Cyclic Voltammetry Mechanistic Investigation. Organometallics, 2018, 38 (6), pp.1280-1285. 10.1021/acs.organomet.8b00555 . hal-02316597

\section{HAL Id: hal-02316597 \\ https://hal-univ-paris.archives-ouvertes.fr/hal-02316597}

Submitted on 15 Oct 2019

HAL is a multi-disciplinary open access archive for the deposit and dissemination of scientific research documents, whether they are published or not. The documents may come from teaching and research institutions in France or abroad, or from public or private research centers.
L'archive ouverte pluridisciplinaire HAL, est destinée au dépôt et à la diffusion de documents scientifiques de niveau recherche, publiés ou non, émanant des établissements d'enseignement et de recherche français ou étrangers, des laboratoires publics ou privés. 


\title{
Molecular Electrochemical Catalysis of the $\mathrm{CO}_{2}$-to- $\mathrm{CO}$ Conversion with a Co Complex: A Cyclic Voltammetry Mechanistic Investigation
}

\author{
Claudio Cometto, ${ }^{\dagger}$ Lingjing Chen, ${ }^{\ddagger}$ Elodie Anxolabéhère-Mallart, ${ }^{\dagger}{ }^{\dagger}$ Claire Fave, ${ }^{\dagger}{ }^{\dagger}$ Tai-Chu Lau, ${ }^{\S}$ \\ and Marc Robert* ${ }^{\dagger}+0$
}

${ }^{\dagger}$ Sorbonne Paris Cité, Laboratoire d’Electrochimie Moléculaire, UMR 7591 CNRS, Université Paris Diderot, 15 rue Jean-Antoine de
Baif, CEDEX 13 F-75205 Paris, France
${ }^{\ddagger}$ School of Environment and Civil Engineering, Dongguan University of Technology, Guangdong 523808, China
${ }^{\S}$ Department of Chemistry, Institute of Molecular Functional Materials, City University of Hong Kong, Tat Chee Avenue, Kowloon
Tong, Hong Kong, China

ABSTRACT: The electrochemical catalytic reduction of $\mathrm{CO}_{2}$ into $\mathrm{CO}$ could be achieved with excellent selectivity and rate in acetonitrile in the presence of phenol with cobalt $2,2^{\prime}: 6^{\prime}, 2^{\prime \prime}: 6^{\prime \prime}, 2^{\prime \prime \prime}$-quaterpyridine complex $\left[\mathrm{Co}{ }^{\mathrm{II}}(\mathrm{qpy})\left(\mathrm{H}_{2} \mathrm{O}\right)_{2}\right]^{2+}(\mathrm{Co})$ acting as a molecular catalyst. Upon using cyclic voltammetry at low and high scan rate (up to $500 \mathrm{~V} / \mathrm{s}$ ) two catalytic pathways have been identified. At a low concentration of phenol $(<1 \mathrm{M})$, catalysis mainly occurs after the reduction of Co with three electrons. In that case, the selectivity for $\mathrm{CO}$ production is ca. $80 \%$ with $20 \%$ of $\mathrm{H}_{2}$ as by product, along with a turnover frequency of $1.2 \times 10^{4} \mathrm{~s}^{-1}$ for CO production at an overpotential $\eta$ of ca. $0.6 \mathrm{~V}$. The triply reduced active species binds to $\mathrm{CO}_{2}$ and the $\mathrm{C}-\mathrm{O}$ bond is cleaved thanks to the acid. At very large concentration of phenol $(3 \mathrm{M})$, another pathway becomes predominant: the doubly reduced species binds to $\mathrm{CO}_{2}$, while its reductive protonation leads to $\mathrm{CO}$ formation. As already shown, this later process is

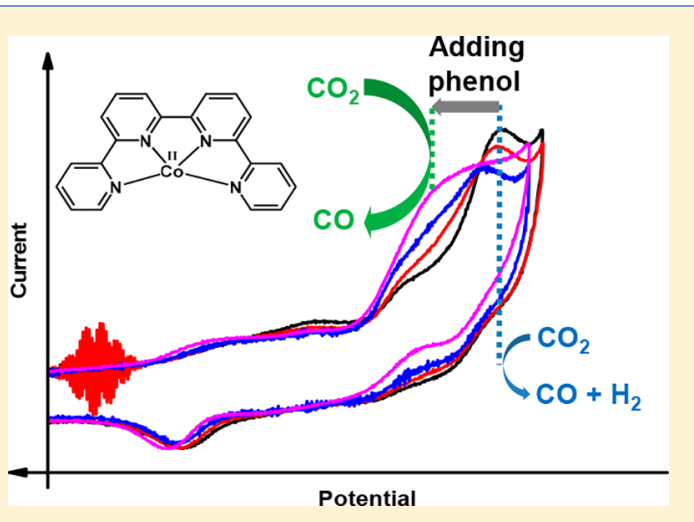
endowed with fast rate at low overpotential (turnover frequency of $3 \times 10^{4} \mathrm{~s}^{-1}$ at $\eta=0.3 \mathrm{~V}$ ) and $95 \%$ selectivity for CO production. By varying the phenol concentration and the scan rate in voltammetry experiments, it was thus possible to identify, activate, and characterize several pathways for the $\mathrm{CO}_{2}$-to- $\mathrm{CO}$ conversion and to decipher Co electrochemical reactivity toward $\mathrm{CO}_{2}$.

\section{INTRODUCTION}

The electrochemical reduction of $\mathrm{CO}_{2}$ has attracted in the recent years a lot of attention, due to the possibility of producing value added chemical as well as fuels, such as methanol or light hydrocarbons. ${ }^{1,2}$ It may have an enormous impact on our industry (electrification of the industry) as well as on our societies. ${ }^{3,4}$ In this perspective, $\mathrm{CO}_{2}$ would be used as a renewable feedstock for storing unlimited, free solar energy (initially transformed into electricity) before reutilizing it for various applications (heating, transportation, etc.). Molecular electrocatalysts are mainly capable of transforming $\mathrm{CO}_{2}$ with two electrons and two protons into either $\mathrm{CO}$ or formic acid, and they have been recently reviewed with great care. $^{5-12}$ Catalysts employing noble metals (e.g., Ru, Re, Pd) as well as earth-abundant metals (e.g., $\mathrm{Co}, \mathrm{Mn}, \mathrm{Fe}$ ) have been used, although the later ones are less numerous. Among those recently proposed for $\mathrm{CO}_{2}$-to- $\mathrm{CO}$ catalytic conversion, the cobalt $2,2^{\prime}: 6^{\prime}, 2^{\prime \prime}: 6^{\prime \prime}, 2^{\prime \prime \prime}$-quaterpyridine $\left[\mathrm{Co} \text { II }(q p y)\left(\mathrm{H}_{2} \mathrm{O}\right)_{2}\right]^{2+}$ (Scheme 1 , noted $\mathbf{C o}$ ) is one of the most promising examples in terms of selectivity, durability, and catalytic rate, being active in acetonitrile $(\mathrm{ACN})$ as solvent both in electrochemical ${ }^{13}$ and
Scheme 1. Structure of the Catalyst $(\mathrm{Co})^{a}$

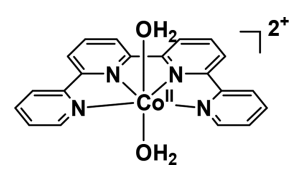

${ }^{a}$ Counter ions $\left(2 \mathrm{ClO}_{4}^{-}\right)$omitted for clarity.

in photochemical conditions under visible light irradiation. ${ }^{14}$ This complex (having $2 \mathrm{Cl}$ atoms as ligand in axial position instead of the water molecules) was recently incorporated in a catalytic ink comprising a mixture of multiwalled carbon nanotubes plus a minimal amount of Nafion and was deposited onto porous carbon paper. ${ }^{15}$ It led to exceptional catalytic activity for $\mathrm{CO}$ production in pure water at close to neutral $\mathrm{pH}$ (7.3) with $99 \%$ selectivity and current densities up to ca. 20 
$\mathrm{mA} / \mathrm{cm}^{2}$ (geometric area) at a low overpotential of $425 \mathrm{mV}$. It is currently the most active and selective molecular supported catalyst for the electrochemical reduction of $\mathrm{CO}_{2}$ in water. We have reported a preliminary study on the catalytic mechanism in organic solvent in the presence of a highly concentrated proton source $\left(3 \mathrm{M}\right.$ phenol). ${ }^{13}$ The role of the acid is to boost the $\mathrm{C}-\mathrm{O}$ bond cleavage. At such high phenol concentration, a first reduction wave produces the $\mathrm{Co}^{\mathrm{I}}$ one-electron-reducedspecies (OERS) that reversibly binds two molecules of phenol in axial position. Upon a second reduction process at potential close to ca. $-1.25 \mathrm{~V}$ vs SCE, the catalyst was shown to activate $\mathrm{CO}_{2}$ and lead to a maximum turnover frequency of $3.3 \times 10^{4}$ $\mathrm{s}^{-1}$ at an overpotential as low as $300 \mathrm{mV}$. However, a more detailed mechanistic study probing the effect and the importance of the applied electric potential and acid concentration on the catalytic pathway is missing. In this connection, in a preliminary study on $\left[\mathrm{Co}^{\mathrm{II}}(\mathrm{qpy})\left(\mathrm{H}_{2} \mathrm{O}\right)_{2}\right]^{2+}$, Che et al. have reported a catalytic process starting at ca. -1.7 $\mathrm{V}$ vs SCE in the absence of any added acid at a potential corresponding to a reduction wave that was assigned to ligand reduction, suggesting that the $\mathrm{CO}_{2}$ may be activated at various potentials by different species. ${ }^{16}$ Different catalytic pathways may thus operate depending on the acid content of the solution and the applied potential.

In this study, we have dissected in detail the reaction pathways for the electroreduction of $\mathrm{CO}_{2}$ into $\mathrm{CO}$ as a function of phenol addition to the solution and of the potential applied to the electrode upon using cyclic voltammetry from 0.1 to $500 \mathrm{~V} \mathrm{~s}^{-1}$ along with complementary controlledpotential electrolysis. It appeared that $\mathrm{CO}_{2}$ could be activated at various potentials depending on the phenol concentration from a doubly or a triply reduced catalyst, respectively. Mechanisms and catalytic rate constants for both processes have been obtained.

\section{RESULTS AND DISCUSSION}

The cyclic voltammetry of $\left[\mathrm{Co}(\mathrm{qpy})\left(\mathrm{H}_{2} \mathrm{O}\right)_{2}\right]^{2+}$ under $\mathrm{Ar}$ atmosphere (Figure 1) shows a first reversible one-electron reduction wave centered on the metal with $E_{1}^{0}\left(\mathrm{Co}^{\mathrm{II}} / \mathrm{Co}^{\mathrm{I}}\right)=$ $-0.565 \mathrm{~V}$ vs SCE, followed by a second one with a standard redox potential $E_{2}^{0}=-0.795 \mathrm{~V}$ vs $\mathrm{SCE}$ (see below). Upon increasing the $\mathrm{H}_{2} \mathrm{O}$ concentration or the scan rate (Figure 2), the second reduction wave evolves to a small plateau-shape current, indicating that it is preceded by the loss of water

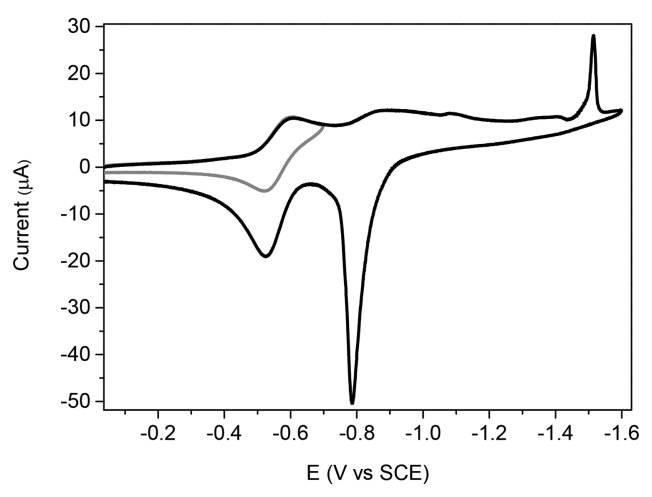

Figure 1. CVs of Co $(0.5 \mathrm{mM})$ in an $\mathrm{ACN}$ solution $+\mathrm{NBu}_{4} \mathrm{PF}_{6}(0.1$ $\mathrm{M})$ under $\mathrm{Ar}$, scan rate $0.1 \mathrm{~V} / \mathrm{s}$. A glassy carbon electrode $(3 \mathrm{~mm}$ diameter) was used as working electrode. The gray trace is restricted to the first redox process (eq 1).
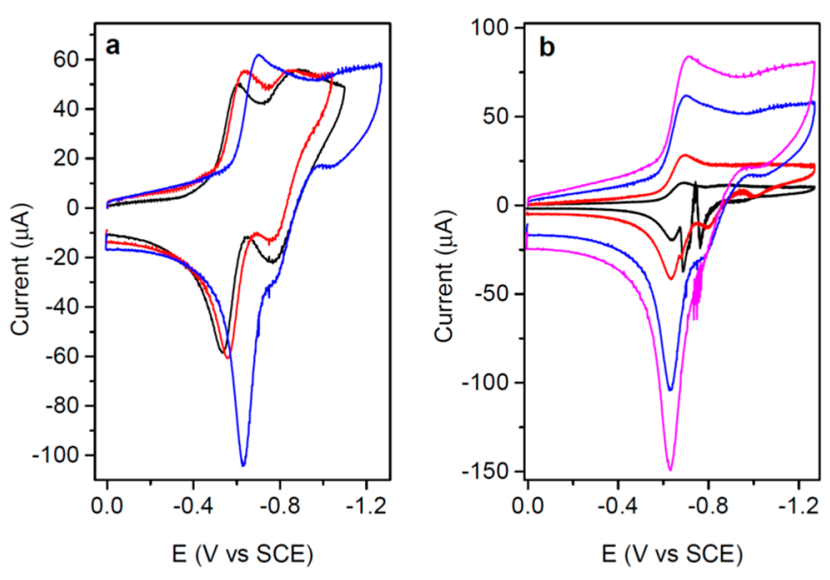

Figure 2. CVs of $\mathrm{Co}(0.5 \mathrm{mM})$ in an $\mathrm{ACN}$ solution $+\mathrm{NBu}_{4} \mathrm{PF}_{6}(0.1$ M) under $\mathrm{Ar}$ : (a) without added $\mathrm{H}_{2} \mathrm{O}$, (black); $+1 \% \mathrm{H}_{2} \mathrm{O}$, (red); + $10 \% \mathrm{H}_{2} \mathrm{O}$ (blue) (scan rate $2.5 \mathrm{~V} / \mathrm{s}$ ), (b) with $10 \%$ added $\mathrm{H}_{2} \mathrm{O}: 0.1$ $\mathrm{V} / \mathrm{s}$ (black); $0.5 \mathrm{~V} / \mathrm{s}$ (red); $2.5 \mathrm{~V} / \mathrm{s}$ (blue), $5 \mathrm{~V} / \mathrm{s}$ (pink). A glassy carbon electrode ( $3 \mathrm{~mm}$ diameter) was used as working electrode.

molecules from the one-electron-reduced $\mathrm{Co}^{\mathrm{I}}$ species $(\mathrm{C}+\mathrm{E}$ mechanism $),{ }^{17}$ as already hypothesized by Che et al. ${ }^{16}$ The following reactions summarize the two redox processes:

$$
\begin{aligned}
& {\left[\mathrm{Co}^{\mathrm{II}}(\mathrm{qpy})\left(\mathrm{H}_{2} \mathrm{O}\right)_{2}\right]^{2+}+\mathrm{e}^{-} \rightleftarrows\left[\mathrm{Co}^{\mathrm{I}}(\mathrm{qpy})\left(\mathrm{H}_{2} \mathrm{O}\right)_{2}\right]^{+}} \\
& {\left[\mathrm{Co}^{\mathrm{I}}(\mathrm{qpy})\left(\mathrm{H}_{2} \mathrm{O}\right)_{2}\right]^{+} \rightleftarrows\left[\mathrm{Co}^{\mathrm{I}}(\mathrm{qpy})\right]^{+}+2 \mathrm{H}_{2} \mathrm{O}} \\
& {\left[\mathrm{Co}^{\mathrm{I}}(\mathrm{qpy})\right]^{+}+\mathrm{e}^{-} \rightleftarrows\left[\mathrm{Co}^{\mathrm{I}}(\mathrm{qpy})^{\bullet-}\right]}
\end{aligned}
$$

The second reduction appears localized on the ligand, ${ }^{13}$ as suggested by DFT calculation (spin-density analysis) so that the neutral $[\mathrm{Co}(\mathrm{qpy})]$ (noted $\left[\mathrm{Co}^{\mathrm{I}}(\mathrm{qpy})^{\bullet-}\right]$ in reaction (3)) can be viewed as a $\mathrm{CO}^{\mathrm{I}}$ species coordinated by a ligand radical anion. This doubly reduced species undergoes adsorption on the electrode surface, as inferred from the sharp desorption peak observed upon reoxidation scan (oxidation peak at ca. $-0.78 \mathrm{~V}$ vs SCE, Figure 1) and from a second desorption peak $\left(E_{\mathrm{p}}=-1.51 \mathrm{~V}\right.$ vs SCE, Figure 1$)$ that corresponds to the third reduction wave of the complex. The adsorption/desorption phenomena made it difficult to obtain qualitative and quantitative data for Co reduction from the analysis of cyclic voltammetry $(\mathrm{CV})$ experiments at low scan rate (i.e., typically $0.1 \mathrm{~V} / \mathrm{s}$ ). However, when raising the scan rate, the charge passing through the electrode surface diminishes, and the amount of adsorbed species could thus be minimized. This is what can be seen from Figure 3, where a scan rate of up to 70 $\mathrm{V} / \mathrm{s}$ was applied, leading to a purely diffusion-controlled third reduction peak (see Figure S1). A standard redox potential $E^{0}$ $=-1.51 \mathrm{~V}$ vs SCE was obtained from this reduction wave that corresponds to the generation of the anionic $[\mathrm{Co}(\mathrm{qpy})]^{-}$ species.

As already described, ${ }^{13}$ upon addition of phenol $(\mathrm{PhOH})$ to a solution of $\mathrm{Co},\left[\mathrm{Co}^{\mathrm{I}}(\mathrm{qpy})\right]^{+}$binds two $\mathrm{PhOH}$ molecules:

$$
\left[\mathrm{Co}^{\mathrm{I}}(\mathrm{qpy})\right]^{+}+2 \mathrm{PhOH} \rightleftarrows\left[\mathrm{Co} \text { (qpy) }(\mathrm{PhOH})_{2}\right]^{+}
$$

with an equilibrium constant $K$ of $0.18 \mathrm{M}^{-2}$. The intensity of the second reduction wave decreases with increasing concentration of phenol (Figure 4, inset), due to limited formation of uncoordinated $\left[\mathrm{Co}^{\mathrm{I}}(\mathrm{qpy})\right]^{+}$. The new species $\left[\mathrm{Co}^{\mathrm{I}}(\mathrm{qpy})(\mathrm{PhOH})_{2}\right]^{+}$is in turn reduced at ca. $-1.25 \mathrm{~V}$, corresponding to a new reduction wave that grows with $[\mathrm{PhOH}]$ (Figure 4). At the largest concentration of phenol 


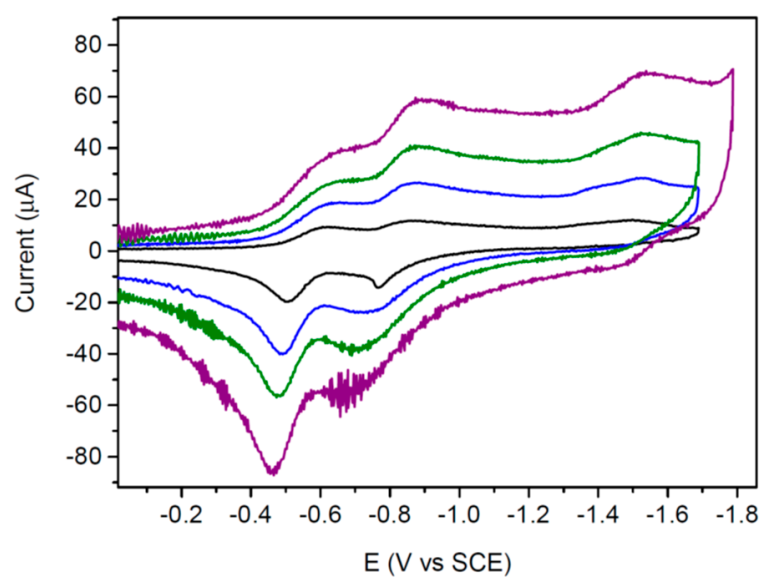

Figure 3. $\mathrm{CVs}$ of $\mathrm{Co}(0.5 \mathrm{mM})$ in an $\mathrm{ACN}$ solution $+\mathrm{NBu}_{4} \mathrm{PF}_{6}(0.1$ M) under Ar: scan rate $5 \mathrm{~V} / \mathrm{s}$ (black), $20 \mathrm{~V} / \mathrm{s}$ (blue), $40 \mathrm{~V} / \mathrm{s}$ (green), $70 \mathrm{~V} / \mathrm{s}$ (purple). A glassy carbon electrode (1 mm diameter) was used as working electrode.

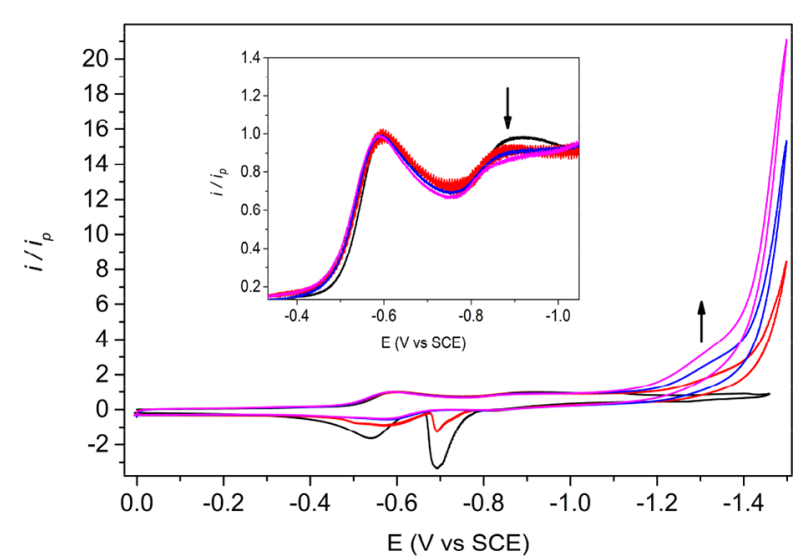

Figure 4. CVs of $\mathrm{Co}(0.5 \mathrm{mM})$ in an $\mathrm{ACN}$ solution $+\mathrm{NBu}_{4} \mathrm{PF}_{6}(0.1$ $\mathrm{M}$ ) under Ar, scan rate $0.1 \mathrm{~V} / \mathrm{s}$, in the absence (black) and presence of $1 \mathrm{M}$ (red), and $1.5 \mathrm{M}$ (blue) and $2 \mathrm{M}$ (magenta) PhOH. Each CV curve is normalized to the first reduction peak current in order to take into account viscosity change and dilution effect. Inset: zoom of the first and second reduction waves. A glassy carbon electrode $(3 \mathrm{~mm}$ diameter) was used as working electrode.

employed ( $3 \mathrm{M}$ ), a marginal shift of the UV absorption band of Co was observed (Figure S2), showing the interaction between $\mathrm{PhOH}$ molecules and $\left[\mathrm{Co}^{\mathrm{II}}(\mathrm{qpy})\left(\mathrm{H}_{2} \mathrm{O}\right)_{2}\right]^{2+}$ is negligible.

When a solution of $\mathrm{Co}$ is purged with $\mathrm{CO}_{2}$ in absence of added acid, no catalysis occurs upon the first three cathodic peaks. Conversely a catalytic wave is produced at more negative potential (potentials negative to ca. $-1.62 \mathrm{~V}$ vs SCE, Figure S3), as already reported by Che et al. ${ }^{16}$ We did not investigate this wave further. Upon gradually increasing the phenol concentration, a current enhancement is observed upon the third reduction peak (Figure 5).

Concomitantly, adsorption phenomena decrease as attested by the progressive disappearance of the reoxidation peak at ca. $-0.8 \mathrm{~V}$ vs SCE, showing that phenol limits interactions between the electro-generated intermediates and the electrode surface. Indeed, formation of $\left[\mathrm{Co}^{\mathrm{I}}(\mathrm{qpy})(\mathrm{PhOH})_{2}\right]^{+}$instead of $\left[\mathrm{Co}^{\mathrm{I}}(\mathrm{qpy})\right]^{+}$upon the first reduction wave avoids $\left[\mathrm{Co}^{\mathrm{I}}(\mathrm{qpy})^{\bullet-}\right]$ production upon the second reduction wave, which is the species prone to adsorption. The complex shape and continuous positive shift of the catalytic wave upon

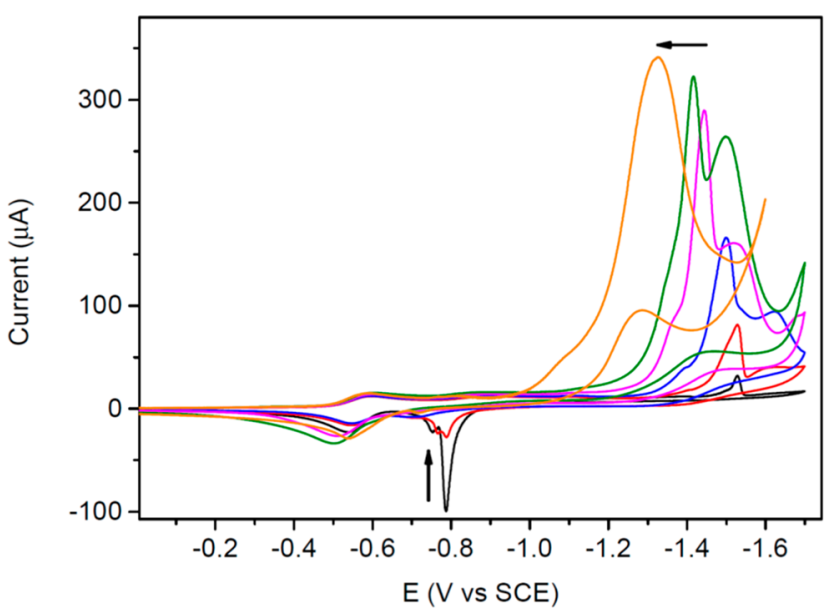

Figure 5. CVs of Co $(0.5 \mathrm{mM})$ in an $\mathrm{ACN}$ solution $+\mathrm{NBu}_{4} \mathrm{PF}_{6}(0.1$ M) under $\mathrm{CO}_{2}$ atmosphere, scan rate $0.1 \mathrm{~V} / \mathrm{s}$, in the absence (black) and presence of $10 \mathrm{mM}$ (red), $30 \mathrm{mM}$ (blue), $130 \mathrm{mM}$ (magenta), $210 \mathrm{mM}$ (green), and $800 \mathrm{mM}$ (orange) $\mathrm{PhOH}$. A glassy carbon electrode ( $3 \mathrm{~mm}$ diameter) was used as working electrode.

increasing $[\mathrm{PhOH}]$ suggests the occurrence of several catalytic processes.

By increasing the scan rate between 50 and $500 \mathrm{~V} / \mathrm{s}$ for very high phenol concentrations $(1-3 \mathrm{M})$, the catalytic peak was distinctively split into two different waves (Figure 6a). The first
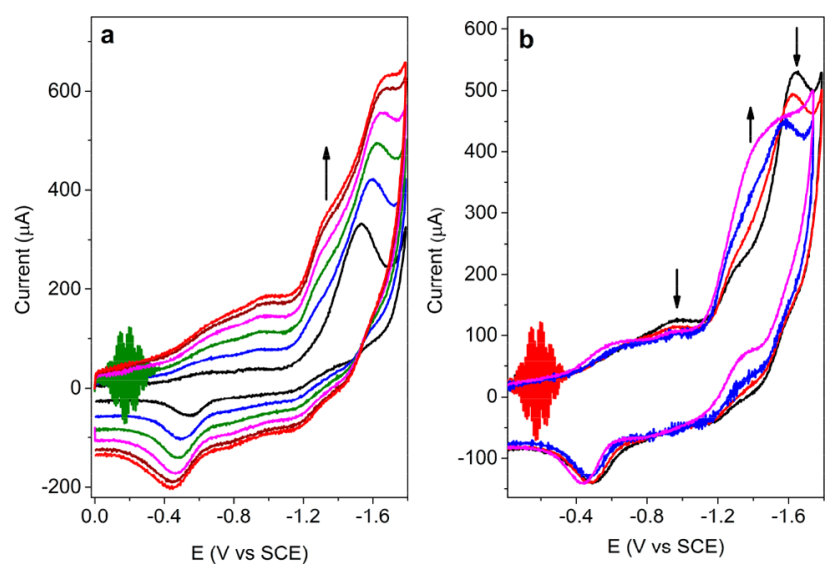

Figure 6. CVs of $\mathrm{Co}(0.5 \mathrm{mM})$ in an $\mathrm{ACN}$ solution $+\mathrm{NBu}_{4} \mathrm{PF}_{6}(0.1$ M) solution under $\mathrm{CO}_{2}$ atmosphere: (a) $+1.5 \mathrm{M} \mathrm{PhOH}$ at $50 \mathrm{~V} / \mathrm{s}$ (black), $150 \mathrm{~V} / \mathrm{s}$ (blue), $250 \mathrm{~V} / \mathrm{s}$ (green), $350 \mathrm{~V} / \mathrm{s}$ (purple), $450 \mathrm{~V} / \mathrm{s}$ (wine), and $500 \mathrm{~V} / \mathrm{s}$ (red). (b) $+1 \mathrm{M}$ (black), $1.5 \mathrm{M}$ (red), $2 \mathrm{M}$ (blue), and $3 \mathrm{M}$ (magenta) $\mathrm{PhOH}$ at $\nu=250 \mathrm{~V} / \mathrm{s}$. A glassy carbon (1 $\mathrm{mm}$ diameter) was used as working electrode.

one is centered at ca. $-1.25 \mathrm{~V}$ vs SCE (indicated by an arrow in Figure 6a), while the second one is observed at ca. $-1.55 \mathrm{~V}$. Both catalytic waves show plateau current at $500 \mathrm{~V} / \mathrm{s}$ (Figure $6 \mathrm{a})$. For a fixed scan rate of $250 \mathrm{~V} / \mathrm{s}$, the first catalytic wave becomes the only process to be observed for $3 \mathrm{M}$ phenol (Figure 6b). Concomitantly, the reductive wave at $-0.95 \mathrm{~V}$ vs SCE corresponding to the formation of $\left[\mathrm{Co}^{\mathrm{I}}(\mathrm{qpy})^{\bullet-}\right]$ almost disappears. These data suggest that two catalytic pathways could be activated by adding phenol as proton source, at overpotentials close to ca. 0.3 and $0.6 \mathrm{~V}$ respectively $\left(E_{\mathrm{CO}_{2} / \mathrm{CO}}^{0}\right.$ $=-0.96 \mathrm{~V}$ vs SCE in this solvent conditions $).{ }^{18}$ The first, most positive one is triggered by the reduction of $\left[\mathrm{Co}^{\mathrm{I}}\right.$ (qpy)$\left.(\mathrm{PhOH})_{2}\right]^{+}$, while the second one requires the reduction of 
$[\mathrm{Co}(\mathrm{qpy})]$ to $[\mathrm{Co}(\mathrm{qpy})]^{-}$. In our previous contribution, we have demonstrated that the first process is highly selective for CO production (catalytic selectivity $>95 \%) .{ }^{13}$ Upon performing a controlled potential electrolysis at $-1.6 \mathrm{~V}$ vs SCE in the presence of $0.1 \mathrm{M} \mathrm{PhOH}$ (Figure S4), conditions into which the second catalytic process is dominant, $\mathrm{CO}$ is the main product ( $72 \%$ Faradaic efficiency FE, $77 \%$ selectivity) with however a significant amount of $\mathrm{H}_{2}(20 \% \mathrm{FE})$.

According to these data, two different catalytic mechanisms (Scheme 2) could be proposed for the $\mathrm{CO}_{2}$ reduction

Scheme 2. Mechanism for the Electrochemical Reduction of $\mathrm{CO}_{2}$ into $\mathrm{CO}$ with $\mathrm{Co}^{a}$
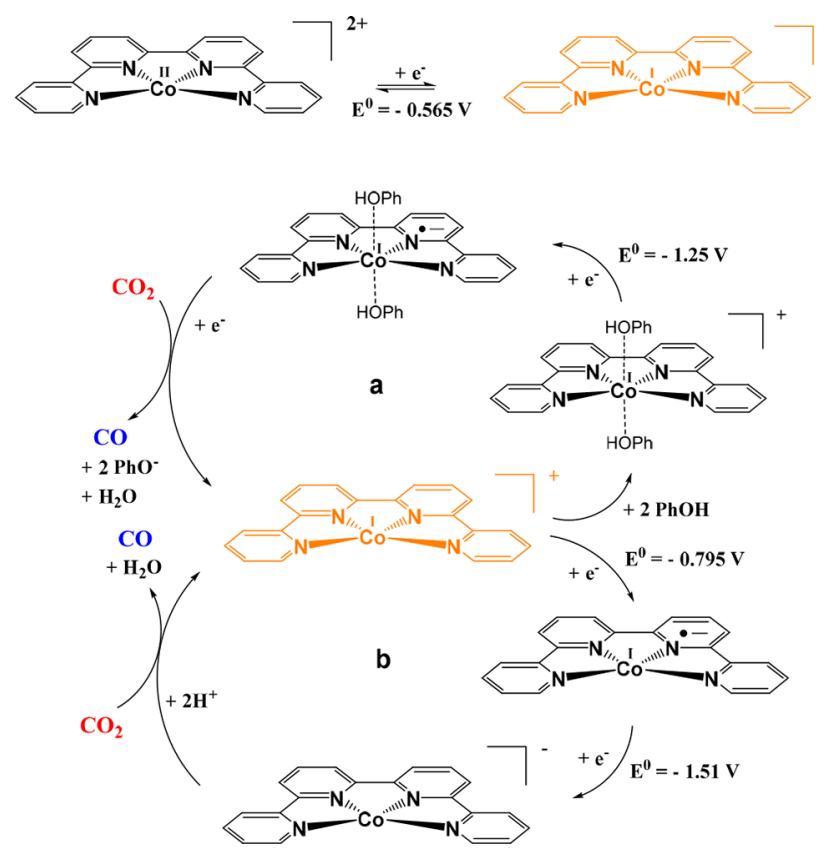

${ }^{a}$ Water molecules in the initial complex are omitted for clarity.

catalyzed by Co, depending on the applied potential and the amount of $\mathrm{PhOH}$ added to the solution. For a very large concentration of phenol $(3 \mathrm{M}),\left[\mathrm{Co}^{\mathrm{I}}(\mathrm{qpy})(\mathrm{PhOH})_{2}\right]^{+}$is produced upon the one-electron reduction of Co (pathway a). Although this species is formally considered as the precursor of the active species $\left[\mathrm{Co}^{\mathrm{I}}(\mathrm{qpy})^{\bullet-}(\mathrm{PhOH})_{2}\right]$, deprotonation of one or two phenolic groups should not be excluded. Pathway $b$ is dominant for a smaller amount of added acid $(<1.5 \mathrm{M})$. In this case, $\left[\mathrm{Co}^{\mathrm{I}}(\mathrm{qpy})\right]^{+}$is reduced to $\left[\mathrm{Co}^{\mathrm{I}}(\mathrm{qpy})^{\bullet-}\right]\left(E^{0}=-0.795 \mathrm{~V}\right.$ vs $\left.\mathrm{SCE}\right)$. Reduction of this later species $\left(E^{0}=-1.51 \mathrm{~V}\right.$ vs $\left.\mathrm{SCE}\right)$ to $[\mathrm{Co}(\mathrm{qpy})]^{-}$triggers the catalysis. The partial loss of selectivity detected during electrolysis at $-1.6 \mathrm{~V}$ vs SCE with $0.1 \mathrm{M}$ phenol can be attributed to the formation of the highly basic species $[\mathrm{Co}(\mathrm{qpy})]^{-}$that may be protonated to an hydride species and further evolve hydrogen, this reaction thus being in competition with $\mathrm{CO}_{2}$ reduction.

At $1 \mathrm{M} \mathrm{PhOH}$, a catalytic plateau independent of the scan rate is observed at large scan rate for pathway $b$, as shown in Figure 7. It is indicative of pure kinetic conditions resulting from mutual compensation between the catalyst diffusion and fast catalytic rate. ${ }^{18}$ Catalysis is purely homogeneous as confirmed by the freely diffusive nature of the third reduction wave (see Figure S1). The catalytic current could be obtained from the CVs: Of the plateau current, $72 \%$ (Figures 7 and S5)

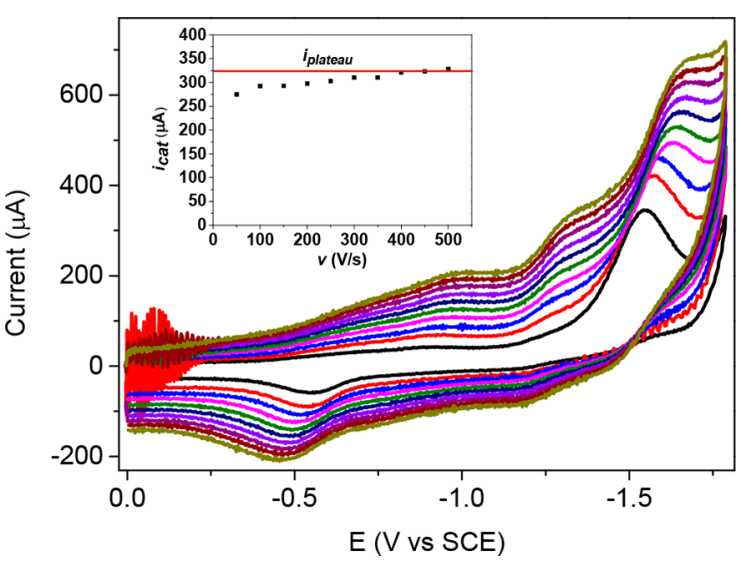

Figure 7. CVs of $\mathrm{Co}(0.5 \mathrm{mM})$ in an $\mathrm{ACN}$ solution $+\mathrm{NBu}_{4} \mathrm{PF}_{6}(0.1$ $\mathrm{M})$ and $\mathrm{PhOH}(1 \mathrm{M})$ under $\mathrm{CO}_{2}$ atmosphere, at $v=50 \mathrm{~V} / \mathrm{s}($ black $)$, $100 \mathrm{~V} / \mathrm{s}$ (red), $150 \mathrm{~V} / \mathrm{s}$ (blue), $200 \mathrm{~V} / \mathrm{s}$ (magenta), $250 \mathrm{~V} / \mathrm{s}$ (olive), $300 \mathrm{~V} / \mathrm{s}$ (navy), $350 \mathrm{~V} / \mathrm{s}$ (violet), $400 \mathrm{~V} / \mathrm{s}$ (purple), $450 \mathrm{~V} / \mathrm{s}$ (wine), and $500 \mathrm{~V} / \mathrm{s}$ (dark yellow). Inset: variation of the catalytic current observed at potentials negative to $-1.5 \mathrm{~V}$ (obtained after subtraction of the background current value) as a function of the scan rate; see Figure S5 for further details. A glassy carbon (1 mm diameter) was used as working electrode.

is due to $\mathrm{CO}_{2}$ reduction (the remaining charge is essentially directed to $\mathrm{H}_{2}$ evolution, assuming similar selectivity as found in potential controlled electrolysis). This current is related to the rate constant $k_{\text {cat }}$ of the catalysis through the following eq 5 corresponding to the mechanism sketched in Scheme 2 (pathway b): ${ }^{19}$

$$
i_{\text {plateau }}=2 F S \times C_{\text {cat }}^{0} \times \sqrt{D_{\text {cat }}} \times \sqrt{k_{\text {cat }}}
$$

where $S$ is the electrode surface, $C^{0}{ }_{\text {cat }}$ is the catalyst concentration, $D_{\text {cat }}$ its diffusion coefficient, and $v$ is the scan rate.

After normalization by the one electron diffusion current of the catalyst (obtained from the first wave reoxidation peak, Figure 7):

$$
i_{\text {peak }}^{0}=0.446 \times F S \times C_{\text {cat }}^{0} \times \sqrt{D_{\text {cat }}} \times \sqrt{\frac{F v}{R T}}
$$

It led to

$$
k_{\text {cat }}=\left(\frac{i_{\text {plateau }}}{i_{\text {peak }}^{0}}\right)^{2} \times \frac{1}{(2 \times 2.24)^{2}} \times \frac{F v}{R T}
$$

and thus $k_{\text {cat }}=1.2 \times 10^{4} \mathrm{~s}^{-1}$, showing the remarkable efficiency of the $\mathrm{CO}_{2}$ reduction process (see the Supporting Information). The rate for catalysis is close to the rate of pathway a $\left(3.3 \times 10^{4} \mathrm{~s}^{-1}\right.$ at $\left.\mathrm{PhOH} 3 \mathrm{M}\right)$ previously obtained.

In conclusion, we have shown that the electrocatalytic reduction of $\mathrm{CO}_{2}$ into $\mathrm{CO}$ by Co could occur through two different mechanisms, depending on the phenol content in the solution. Both pathways necessitate the assistance of the weak proton source to boost the $\mathrm{C}-\mathrm{O}$ bond cleavage. The most positive pathway is activated with an overpotential $\eta$ of ca. 300 $\mathrm{mV}$ and is predominant at very large concentration of acid (3 $\mathrm{M})$. The second one occurs with $\eta=600 \mathrm{mV}$ and is activated at smaller acid concentrations. Both processes are endowed with rate constant in the range of $10^{4} \mathrm{~s}^{-1}$, illustrating the high efficiency of the catalyst. By adjusting the acid concentration and the scan rate, both mechanisms could be characterized 
independently from analysis of the CVs, showing the power of cyclic voltammetry to access mechanistic and kinetic data for catalytic processes.

\section{EXPERIMENTAL SECTION}

Chemicals. Acetonitrile (Acros, > 99.9\%, extra dry over molecular sieves) and supporting electrolyte $\mathrm{NBu}_{4} \mathrm{PF}_{6}$ (Fluka, purriss.) were used as received. Co was synthesized as previously reported. ${ }^{14}$ Phenol was purchased from Sigma-Aldrich and used without further purification.

Electrochemistry and Spectroscopic Analysis. All the experiments have been performed by using dry acetonitrile as solvent and $\mathrm{NBu}_{4} \mathrm{PF}_{6}$ as supporting electrolyte. Before each experiment, the solution was purged with $\mathrm{Ar}$ or $\mathrm{CO}_{2}$ for $20 \mathrm{~min}$.

Cyclic Voltammetry. The working electrode was a $3 \mathrm{~mm}$ diameter glassy carbon (Tokai) disk carefully polished using diamond paste of various size (from 15 to $1 \mu \mathrm{m}$ ) and ultrasonically rinsed in absolute ethanol and dried before use. The counter electrode was a platinum wire, and the reference electrode was an aqueous SCE electrode. All experiments were carried out under argon or carbon dioxide atmosphere at $20{ }^{\circ} \mathrm{C}$, the double-walled jacketed cell being temperature-controlled by circulation of water. $\mathrm{CV}$ data were obtained by use of a Metrohm AUTOLAB instrument. Ohmic drop was compensated using the positive feedback compensation implemented in the instrument. For high speed cyclic voltammetry, a $1 \mathrm{~mm}$ diameter glassy carbon was used as working electrode, and a homemade potentiostat was used for ohmic drop compensation.

Controlled Potential Preparative Scale Electrolysis. Electrolysis reactions were performed using a Princeton Applied Research (PARSTAT 2273) potentiostat. Experiments were carried out in a two-compartment cell with a glassy carbon plate as working electrode. The volume of the solution was $3 \mathrm{~mL}$, and active surface area was 1.8 $\mathrm{cm}^{2}$. The reference electrode was an aqueous SCE electrode, and the counter electrode was a platinum wire positioned in a bridge separated from the cathodic compartment by a ceramic frit, containing a $2 \% \mathrm{H}_{2} \mathrm{O}+0.1 \mathrm{M} \mathrm{NBu}_{4} \mathrm{PF}_{6} \mathrm{ACN}$ solution. The electrolysis solution was purged with $\mathrm{CO}_{2}$ during $20 \mathrm{~min}$ prior to electrolysis. The ohmic drop between working electrode and reference electrode was minimized by dipping the former one directly in the solution and positioning it close to the working electrode. All CPE experiments have been performed under stirring.

Gas Chromatography. Analyses from the gas evolved in the headspace during electrolysis were carried out with an Agilent Technologies 7820A GC system equipped with a thermal conductivity detector. $\mathrm{CO}$ and $\mathrm{H}_{2}$ production were quantitatively assessed using a CP-CarboPlot P7 capillary column $(27.46 \mathrm{~m}$ in length and $25 \mu \mathrm{m}$ internal diameter). Temperature was held at $150{ }^{\circ} \mathrm{C}$ for the detector and $34{ }^{\circ} \mathrm{C}$ for the oven. The carrier gas was argon flowing at $9.5 \mathrm{~mL} / \mathrm{min}$ at constant pressure of 0.5 bar. Injection was performed via a $250 \mu \mathrm{L}$ gas-tight container (Hamilton). These conditions allowed for separation of both $\mathrm{H}_{2}, \mathrm{O}_{2}, \mathrm{~N}_{2}, \mathrm{CO}$, and $\mathrm{CO}_{2}$. Calibration curves for $\mathrm{H}_{2}$ and $\mathrm{CO}$ were determined separately by injecting known quantities of pure gas.

For the formic acid analysis, a $500 \mu \mathrm{L}$ sample of the solution was diluted into $9 \mathrm{~mL}$ of $\mathrm{H}_{2} \mathrm{O}$, filtered and analyzed with a Dionex ICS1100 Ionic Chromatography System equipped with a IonPac AS15 column (KOH $20 \mathrm{mM}$ as eluent).

UV-Visible Spectroscopy. UV/vis Varian Cary 60 Spectrophotometer has been employed for recording the UV-visible spectra. A $0.05 \mathrm{mM}$ solution of Co was used, and the temperature was kept constant at $25^{\circ} \mathrm{C}$ by a thermostat. Each spectrum was recorded under Ar atmosphere in a $1 \mathrm{~cm}$ path length quartz cell.

\section{AUTHOR INFORMATION}

\section{Corresponding Author}

*E-mail: robert@univ-paris-diderot.fr. ORCID

Elodie Anxolabéhère-Mallart: 0000-0002-8708-802X

Claire Fave: 0000-0001-8146-8702

Tai-Chu Lau: 0000-0002-0867-9746

Marc Robert: 0000-0001-7042-4106

Notes

The authors declare no competing financial interest.

\section{ACKNOWLEDGMENTS}

The work described in this paper was supported by Hong Kong University Grants Committee Area of Excellence Scheme (AoE/P-03-08), the National Science Foundation of China (No. 21703034) and the French National Agency for Research (ANR-16-CE05-0010-01). A Ph.D. fellowship to C.C. from Université Sorbonne Paris Cité (USPC) is gratefully acknowledged. Partial financial support to M.R. from the Institut Universitaire de France (IUF) is gratefully acknowledged. G. Thoraval (Université Paris Diderot) is warmly thanked for the design and production of the glassy carbon electrodes.

\section{REFERENCES}

(1) Jhong, H.-R. M.; Ma, S.; Kenis, P. J. Electrochemical conversion of $\mathrm{CO}_{2}$ to useful chemicals: current status, remaining challenges, and future opportunities. Curr. Opin. Chem. Eng. 2013, 2, 191-199.

(2) Aresta, M.; Dibenedetto, A.; Angelini, A. Catalysis for the valorization of exhaust carbon: from $\mathrm{CO}_{2}$ to chemicals, materials, and fuels. Technological use of $\mathrm{CO}_{2}$. Chem. Rev. 2014, 114, 1709-1742.

(3) Tatin, A.; Bonin, J.; Robert, M. A case for electrofuels. ACS Energy Lett. 2016, 1, 1062-1064.

(4) Seh, Z. W.; Kibsgaard, J.; Dickens, C. F.; Chorkendorff, I.; Nørskov, J. K.; Jaramillo, T. F. Combining theory and experiment in electrocatalysis: Insights into materials design. Science 2017, 355, eaad4998.

(5) Costentin, C.; Robert, M.; Savéant, J.-M. Catalysis of the electrochemical reduction of carbon dioxide. Chem. Soc. Rev. 2013, 42, $2423-2436$.

(6) Qiao, J.; Liu, Y.; Hong, F.; Zhang, J. A review of catalysts for the electroreduction of carbon dioxide to produce low-carbon fuels. Chem. Soc. Rev. 2014, 43, 631-675.

(7) Loewen, N. D.; Neelakantan, T. V.; Berben, L. A. Renewable formate from $\mathrm{C}-\mathrm{H}$ bond formation with $\mathrm{CO}_{2}$ : using iron carbonyl clusters as electrocatalysts. Acc. Chem. Res. 2017, 50, 2362-2370.

(8) Elgrishi, N.; Chambers, M. B.; Wang, X.; Fontecave, M. Molecular polypyridine-based metal complexes as catalysts for the reduction of $\mathrm{CO}_{2}$. Chem. Soc. Rev. 2017, 46, 761-796.

(9) Grice, K. A. Carbon dioxide reduction with homogenous early transition metal complexes: Opportunities and challenges for developing $\mathrm{CO}_{2}$ catalysis. Coord. Chem. Rev. 2017, 336, 78-95.

(10) Grills, D. C.; Ertem, M. Z.; McKinnon, M.; Ngo, K. T.; Rochford, J. Mechanistic aspects of $\mathrm{CO}_{2}$ reduction catalysis with manganese-based molecular catalysts. Coord. Chem. Rev. 2018, 374, $173-217$.

(11) Kuramochi, Y.; Ishitani, O.; Ishida, H. Reaction mechanisms of catalytic photochemical $\mathrm{CO} 2$ reduction using $\mathrm{Re}(\mathrm{I})$ and $\mathrm{Ru}(\mathrm{II})$ complexes. Coord. Chem. Rev. 2018, 373, 333-356.

(12) Francke, R.; Schille, B.; Roemelt, M. Homogeneously catalyzed electroreduction of carbon dioxide-Methods, mechanisms, and catalysts. Chem. Rev. 2018, 118, 4631-4701. 
(13) Cometto, C.; Chen, L.; Lo, P.-K.; Guo, Z.; Lau, K.-C.; Anxolabéhère-Mallart, E.; Fave, C.; Lau, T.-C.; Robert, M. Highly selective molecular catalysts for the $\mathrm{CO}_{2}$-to- $\mathrm{CO}$ electrochemical conversion at very low overpotential. Contrasting $\mathrm{Fe}$ vs. Co quaterpyridine complexes upon mechanistic studies. ACS Catal. 2018, 8, 3411-3417.

(14) Guo, Z.; Cheng, S.; Cometto, C.; Anxolabéhère-Mallart, E.; Ng, S. M.; Ko, C. C.; Liu, G.; Chen, L.; Robert, M.; Lau, T. C. Highly efficient and selective photocatalytic $\mathrm{CO}_{2}$ reduction by iron and cobalt quaterpyridine complexes. J. Am. Chem. Soc. 2016, 138, 94139416.

(15) Wang, M.; Chen, L.; Lau, T.-C.; Robert, M. Hybrid Co quaterpyridine complex / carbon nanotube catalytic material for $\mathrm{CO}_{2}$ reduction in water. Angew. Chem., Int. Ed. 2018, 57, 7769-7773.

(16) Lam, K.-M.; Wong, K.-Y.; Yang, S.-M.; Che, C.-M. Cobalt and nickel complexes of $2,2^{\prime}: 6^{\prime}, 2^{\prime \prime}: 6^{\prime \prime}, 2^{\prime \prime}$-quaterpyridine as catalysts for electrochemical reduction of carbon dioxide. J. Chem. Soc., Dalton Trans. 1995, 1103-1107.

(17) Savéant, J.-M. Elements of Molecular and Biomolecular Electrochemistry: An Electrochemical Approach to Electron Transfer Chemistry; John Wiley \& Sons: Hoboken, NJ, 2006; Chapter 2.

(18) Azcarate, I.; Costentin, C.; Robert, M.; Saveant, J.-M. Throughspace charge interaction substituent effects in molecular catalysis leading to the design of the most efficient catalyst of $\mathrm{CO}_{2}$-to-CO electrochemical conversion. J. Am. Chem. Soc. 2016, 138, 1663916644.

(19) Costentin, C.; Saveant, J.-M. Multielectron, multistep molecular catalysis of electrochemical reactions: Benchmarking of homogeneous catalysts. ChemElectroChem 2014, 1, 1226-1236. 